\title{
Implementing Problem based Learning Method in Teaching Arabic Syntax
}

\author{
Nur Qomari ${ }^{1}$ and Khafid Roziki ${ }^{1}$ \\ ${ }^{I}$ Fakultas Humaniora UIN Maulana Malik Ibrahim Malang
}

Keywords: Problem based learning, Teaching Arabic, Syntax

\begin{abstract}
The low ability of students to understand Arabic grammar requires the right learning method given the limited time of the study. Problem-based learning as an alternative method used by language and Arabic lecturers in teaching Arabic grammar especially syntax has provided a solution for students who have difficulty. The method used in this study is qualitative, with a type of case study research. Case study research has the characteristics of investigating phenomena in real-life contexts and carried out on ongoing events or symptoms. The results of this study indicate that the PBL Method is applied to understand Arabic grammar that is familiar to students such as mubtadak, khobar, fail, Naibul fail, kaana wa akhowatuha, Inna wa akhowatuha. In addition, in order to understand these materials students feel easy and even more varied in finding the forms and models of Arabic language expressions that have the structure of the mubtadak khobar, fiil fail, you are familiar with, and broken and so on, because students can explore their own abilities through the problem given by the lecturer to be solved.
\end{abstract}
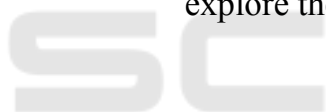

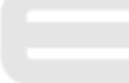

\section{$1-$ INTRODUCTION}

Nahwu in Arabic is like a key which if someone has held the key, he will easily open the doors of knowledge related to Arabic such as the interpretation of al Quran, hadith interpretation or theology and Sufism which speak Arabic directly. Therefore learning from the Department of Arabic Language and Literature must be marketed and not enough for just one semester but will continue for up to three semesters.But in reality, not all graduates or students of Arabic language and literature of UIN Maulana Malik Ibrahim Malang can understand the nahwu materials that have been taught by the lecturers in the class. This is evident when they tested their nahwu ability on a comprehensive examination (the exam held before the thesis exam), the average student was very minimal in understanding his knowledge and could not even identify the basic structure in the Arabic language. Like the khobar mubtadak structure, fiil fail, kaana wa akhowatuha, inna wa akhowatuha and other. Even though the lecturers have applied methods that are in accordance with the character of learning
Arabic grammar, such as the problem-based learning method, especially on materials that can indeed be applied with that method. However

This research will contribute to the accuracy of the use of Arabic grammar learning methods (Nahwu). Considering the importance of this course for students who are engaged in Arabic language and literature. In addition, it will also help lecturers to evaluate learning so far.

\section{LITERATURE REVIEW}

Method of Problem based Learning methods are all things contained in each teaching process, both for teaching mathematics, art, sports, natural sciences and so on. In other words, methods are general systematics for the selection, preparation, and presentation of linguistic material (Abdul Hamid: 2012: 2). Problem - based learning is a learning approach that directs students to become independent learners who are actively involved in group problems. PBL leads to solving a problem in real life that students might face using "problem- 
solving" skills. This learning model is usually in the form of a project to be completed by a group of students who must work together. (Ahmad Fuad Effendy: 2012: 213)

The steps to implement PBL-based nahwu learning according to Effendi (2012: 214) are as follows

1. Students are given a problem or a puzzle of nahwu.

2. In small groups, students discuss the problem using the knowledge they already have and do what needs to be known. This section includes making problem statements and making hypotheses.

3. Then students look for data about things that are needed or information that does not yet exist. 4. Students reunite with their groups to report what they have learned.

5. These steps will repeat several times, discuss, find information, report to the group, discuss again until the group gets the solution. The final activity is the closing discussion activity, namely if the information they learn and the process has arrived at a solution.

Nahwu is a science which discusses an arrangement of words and anything related to tarakib (arrangement of words or sentences) and this study studies the relationship between several words in a sentence and also discusses the relationship between several sentences in an expression. (Ratib Qosim Asyur: 2010: 203). While the equivalent of the word "Nahwu" is Syntax. Syntax according to Henry Thunder Tarigan is one of the grammatical branches that examines sentence structures, clauses, and phrases. (Henry Guntur Tarigan: 2009: 4).In Arabic syntactic learning, there are several differences between groups that agree on nahwu learning separately from language and group skills which agree on nahwu learning which cannot be separated from learning language skills. But in this paper, the adviser will present opinions that agree on nahwu learning separately from learning other language skills. This is because it is in accordance with the topic of discussion in this paper.

Among the reasons for groups that agree with Nahdlat taught separately are:

1. Because Nahwu's grammar can actually help us to uncover mistakes in order to avoid them when speaking and writing.

2. Because actually imitating Arabic fushah from the surrounding environment at this time did not get a chance because the Arabic language had dominated even at the time of Arabic language lessons.

3. Nahwu's grammar can educate students to be able to think logically, be detailed, be strong in judgments, and conduct research and are skilled in concluding.4. In fact, the difficulty of understanding the nahwu grammar is based on the characteristics of the school curriculum, teaching methods, and exam models. Not because of the essence of nahwu itself.

\section{METHODS}

The approach used in this study is a qualitative approach, with a type of case study research. Case study research has the characteristics of investigating phenomena in real-life contexts and carried out on ongoing events or symptoms and not events or symptoms that have been completed (expost facto) by emphasizing the depth of analysis in certain specific cases. This research was conducted at the Arabic Language and Literature Department of Maulana Malik Ibrahim UIN Malang. He chose the Arabic Language and Literature department of Maliki UIN Malang as the object of research because the BSA Department of the Humanities Faculty of Malin Malang UIN was considered new in Nahwu's learning process using the PBL method. In this study, the researcher acts as the main instrument, namely as an observer, and at the same time as a data collector. As an observer, researchers observe learning activities in the classroom that apply the PBL method in the learning process. As an interviewer, researchers interviewed students who were taught using the PBL method in classroom learning, BSA department chair and BSA students and related parties to explore data and find out their opinions related to the implementation of PBL in Nahwu's learning BSA department Maliki UIN Malang.

Primary data is obtained and collected directly from informants through observations, field notes, and interviews with students taught by Nahdlatul Ulama using the PBL method in the class, BSA department chairman and other relevant parties. Secondary data, namely data collected, processed and presented by other parties, usually in the form of publications or journals. This study uses interview techniques, observation, and documentation in data collection.

\section{DISCUSSION}

Problem-based learning in teaching mubtadak involves students in finding the position of mubtadak in each sentence given by the lecturer. With this method students can understand mubtadak without having to memorize the definition. In 
khobar learning by using this method, students are told to identify khobar in every word that has a community dhummah. Of course, after they learned about the characteristics of the lecturer explanation. To determine the file, students are told to identify the words dhummah that are the community that fall after fiil. After learning fails, it is continued with learning fail fail. In learning to fail fail, students are introduced to the first fiq-fiil majhul. After knowing the fiil-fiil, then students are invited to determine whether it fails or fails. When students understand the khobar mubtadak, to determine khobar kaana is very easy. Because the charity is just different in the khobar. If the khobar mubtadak is read rafa 'while the khobar kana is read nasab. In the method of problem-based learning in learning kaana wa akhowatuha emphasized the changes in kana and khoobar kaana furniture. This is because students already know the structure of the cob. In learning at Inna and his siblings almost the same as learning in kaana wa akhowatuha.

While the form of student responses to the application of the problem-based learning method is divided into three types. 1) students feel that using the Problem Based Learning (PBL) method is increasingly able to understand the nahwu material being taught, 2) students feel that there is no incriminating thing to understand nahwu because in this method the highlight is that the reality of language is not just theory, 3) students feel that independence in doing nahwu tasks is increasing considering this method always involves students in the learning process.

DiscussionThere is a study from E. Karabutova about teaching communicative competence based on the schematic structure of stories (story grammar). The results of this study indicate that grammar stories can help in the process of teaching communication competencies. According to Dina Ali Abdalla Ali in the results of his research entitled The Effect of Communicative Approach on Teaching Grammar to EFL Learners: A case study of Wad Babi Secondary School, Khartoum Sudan. Ali said that the teaching of grammar with a communicative approach made the students' communication skills in the real world grow and increase. at the same time, learners can master grammar well.

The two studies both examined grammar in language learning, but the two studies did not answer the issue of research on Arabic grammar learning using the problem-based learning approach. Therefore, the research seeks to provide new insights into the pattern of Arabic grammar learning methods.

\section{CONCLUSION}

Problem-based learning contributes a lot to students, especially in the technique of understanding grammar in Arabic, specifically syntax. This method helps students to understand Arabic grammar easily, making students no longer phobic about syntax courses, because, with this method, the syntax of Arabic can be learned easily. And also make students more independent in learning the syntactic material.

\section{REFERENCES}

Abdul Chaer, Psikolinguistik Kajian Teoritik, Jakarta : PT. Rineka Cipta.

Abdullah idi, 2010, Pengembangan Kurikulum Terori dan Praktik, Jogjakarta : Ar-Ruzz Media

Ahmad Fuad Effendy, 2012, Metodologi Pengajaran Bahasa Arab, Malang : Misykat

Bisri Musthofa dan Abdul Hamid, 2012, Metode dan Strategi Pembelajaran Bahasa Arab, Malang : UINPress

Kartini Kartono, 1990, Pengantar Metodologi Reserach Sosial, Bandung : CV. Mandar Maju

Lexy J. Moleong, 2007, Metodologi Penelitian Kualitatif; Edisi Revisi, Bandung : PT Remaja Rosda Karya

Lukas, 1982, Masalah Wawancara dengan Informan Pelaku Sejarah di Jawa. Aspek Manusia dalam Penelitian masyarakat,Jakarta : Gramedia

Masri Singarimbun dan Sofyan Efendi, 1994, (ed)., Metode Penelitian Survey, Jakarta : LP3ES

Mattew B. Miles dan A. Michelle Haberman, 1992, An Expanded Sourcebook Qualitative Data Analysis, second Edition, terj. Tjejep R. Rohidi, Anallisis Data Kualitatif, Jakarta : UI-Press

Muhaimin, 2012, Pengembangan kurikulum Pendidikan Agama Islam di Sekolah, Madrasah dan perguruan tinggi, Jakarta : PT. RajaGrafindoPersada

Muhammad Rifa'I, 2011, Poilitik Pendidikan Nasional, Jogjakarta : Ar- Ruzz Media.

Nana Syaodih Sukmadinata,2007, Pengembangan Kurikulum Teori dan Praktek, Bandung : PT.Remaja Rosda Karya.

Nasution, 1996, Metodologi Penelitian Naturalistik Kualitatif, Bandung : Tarsito

Noeng Muhadjir, 1989, Metodologi Penelitian Kualitatif, Yogyakarta : Raka Sarasin

Oemar H. Malik, 2007, Kurikulum dan Pembelajaran, Jakarta : PT. Bumi Aksara

Oemar Hamalik,2006, Manajemen Pengembangan Kurikulum, Bandung : PT. Remaja Rosda Karya. 
Robert S Bogdan \& sari Knope, 1982, Qualitative Research For Education an Introduction to Theory and Methods, Boston : Allynan Bacon

Sardiman, 2007, Interaksi dan Motivasi Belajar-mengajar, , Jakarta : Raja Grafindo Persada

Suharsimi Arikunto dan Cepi Safruddin Abdul Jabar, 2007, Evaluasi Program pendidikan Pedoman teoritis praktis bagi praktisi pendidikan, Jakarta : PT. Bumi Aksara

Suharsimi Arikunto, 2002, Prosedur Penelitian. Suatu Pendekatan Prakteka, Jakarta : Rineka Cipta

Sutopo, 1996, HB Metode Penelitian Kualitatif, Metodologi Penelitian Untuk Ilmu-Ilmu Sosial dan Budaya, Surakarta : UNS

Sutrisno Hadi, 1994, Metodologi Reserach II,(Yogyakarta : Andi Offset

Universitas Islam Negeri (UIN) Malang, Pedoman Pendidikan Tahun Akademik 2004/2005 